\title{
国立大学における福利厚生施設の整備特性に関する研究 THE PRESENT STOCKS OF WELFARE FACILITIES ON THE NATIONAL UNIVERSITY CAMPUSES
}

\author{
金 鍾 石*, 宮本文人**, 志水·英樹*** \\ Jongseok KIM, Fumihito MIYAMOTO and Hideki SHIMIZU
}

\begin{abstract}
The purpose of this paper is to grasp the present stocks of welfare facilities on national university campuses, that is, student unions, cafeteria, health service center, club buildings and etc, . Data about areas, numbers, and plans of buildings were collected from 112 campuses of 81 universities. The consequences are as followers:

1) The present stocks of welfare facilities are not sufficient for students on campuses, because facilities for lecture, research, experiment, and were build at first under the limits of budget. 2) When coping with increasing of students, complex buildings which contained some small facilities were supplied. Complex building invited confusion of functions, but were useful for future development.
\end{abstract}

Keymords: National University Campus, Complex Buildings, Student Union, Cafeteria, Health Service Center, Club building

国立大学団地、複合施設、大学会館、食堂、保健管理センター、学生サークル部室

\section{1. 研究の背景と目的}

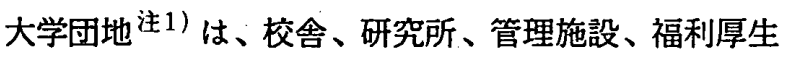
施設、図書館、情報処理センター、体育施設など様々な 機能の建物や機能が複合した建物から構成されている。

国立大学における施設整備の経緯を概観すると次のと おりである。昭和 24 年の新制大学制度の発足以来、大学 数が増え、大学にふさわしい施設の整備は重要な課題と なった。当初は、予算的制約から学部校舎の量的な整備 が中心となった。昭和30年代半ば以降の急激な高度経済 成長から石油危機直後の昭和50年くらいまでは、大学進 学率の増加に伴い学生数も急速に増加した。大学では教 育研究に必要な講義室、実験室、研究室などを確保する ために学部校舎がやはり優先的に整備された。福利厚生 施設は整備が遅れたが、特記すべきことは、昭和 32 年に 国立大学で最初の大学会館が建設されたことである。そ れは北海道大学のクラーク記念会館である。昭和 40 年代 に入ると、日本の経済む大きく発展し、福利厚生施設を 整備する余裕む出てきた。
福利厚生施設は団地内で学生や教職員の生活を支える 役割を担っているが、学生の生活は所属学部により大き く異なる。団地における学部構成により、福利厚生施設 の在り方は異なるともいえる。食堂、売店などは、市街 地の団地では周辺の店舖で代替できる。このような個々 の団地の状況を考慮して整備されたため、福利厚生施設 は面積が十分でなくとも機能してきたと推测される。

また、大学では長期的に予測できない組織の拡充が度 々ある。学部や学科などの新増設に伴う学生数の増加に 対応して、校舎の他に福利厚生施設の整備が必要となる。 その際、単体の建物として建設するには面積が不足する 場合などが多く、福利厚生施設は度々他の用途の施設と 複合する形で建物が新築されてきた。複合施設としての 福利厚生施設の在り方も検討する余地がある。

福利厚生施設は原則として建物基準面積注 2 ) に基づき 整備される。この基準面積は、巨視的な観点から量的に 施設を整備する目安である。この基準は、個々の施設が 十分に機能したり、利用者の快適さや満足度を保証する

Graduate Student, Tokyo Institute of Technology, M. Eng.

Assoc. Prof., Research and Development Center for Educational

Facilities, TTokyo Institute of Technology, Dr. Eng.

Prof., Research and Development Center for Educational Facilities, Tokyo Institute of Technology, Dr. Eng. 
ために面積が十分であるというのではなく、単に一定の 水準への到達を示す指標の一つである。

今後、より質の高い施設にするには、単に基準面積の 充足を目標とした一律な整備ではなく、現状の基準面積 を越えたとしても団地の状況や将来構想を考慮した計画 と整備が必要である。このような整備は、巨視的にみる と限られた予算の効率的運用にすつながる。いずれにせ よ、現在の建物基準面積を最低限充足することが、福利 厚生施設を整備する上での必要条件であると思われる。

本研究では、国立大学団地の福利厚生施設について、 1) 建物基準面積の充足からみた整備状況、2)他の用途亡 の複合状況、さらに、3) 整備にかかわる諸要因との関係 の分析を通して、施設整備の経緯と現況を把握し、将来 の福利厚生施設の整備を巨視的に考える上での基礎的資 料とすることを目的とする。

\section{2. 調查の概要}

\section{1 福利厚生施設の分類}

国立大学において、福利厚生施設は施設の機能からみ て、次の三つに分類されている。すなわち、(1)食堂、売 店などの福利施設、(2)保健室、保健管理センターなどの 保健管理施設、(3)学生サークル部室、合宿研修施設など の課外活動施設である。本研究では、この分類に従い分 析を行うことにした（表1）。

\section{2 研究対象と調查方法}

研究対象としては、現在の一般的な福利厚生施設の状 況を取り上げるために、国立大学団地から病院などの特 殊な施設をむつ医学部単独団地を除き、学部がある団地 を選んだ。対象とした数は81大学 112 団地で、団地別に 昭和 63 年度時点で敷地や建物の面積関係のデー夕、福利 厚生施設の面積関係のデータ、平面図を収集した。

\section{3. 福利厚生施設の現状}

3.1 福利厚生施設の整備に関連する団地特性

大学団地はそれぞれの団地成立の時代背景、規模、人 的条件などを反映し、実に様々である。その多種多様な 団地の状況と福利厚生施設の整備に関係があると思われ るいくつかの団地特性を取り上げて検討した。

(1) 学部構成による団地類型 : 団地別の学部構成は多 様である。学生の生活は所属学部により異なるので、実 態に即して考えると、学部構成により整備状況が異なる 可能性がある。

表 2 は、最初に学部を 5 タイプ (1)文科系学部、(2)理 科・農科系学部、(3)工科系学部、(4)教員養成を主とした 教育学部、(5)その他の学部) に分類し、この学部分類を むとに団地の学部構成を大きく 6 類型に、さらに、学科
表 1 福利厚生施設の分類

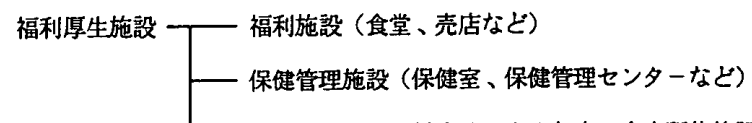

課外活動施設（学生サークル部室、合宿研修施設など） 注）大学会馆は他の機能の施設と被合して建設されている場合が多いので、福利施設とは 区別して扱った また、棵外活動施設の中で、海の家、山の家などは除外した

表 2 学部構成による団地類型

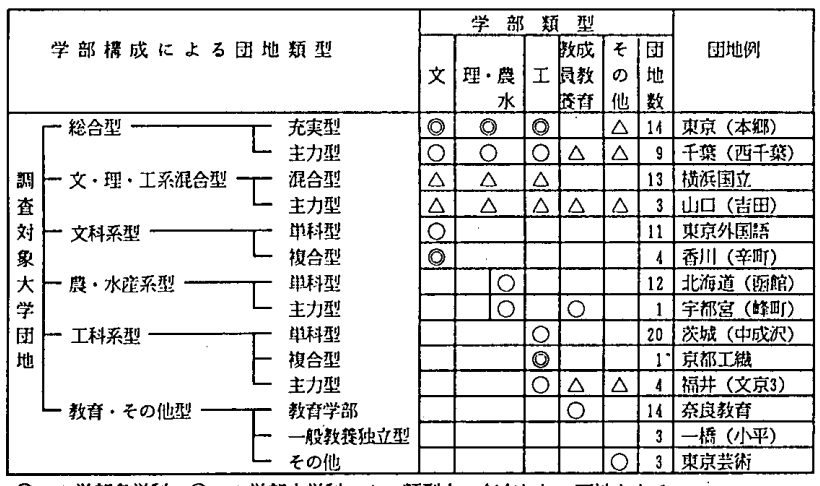

(○: 1 学部多学科、 $O: 1$ 学部少学科、 $\triangle:$ 類型內に存在しない団地もある

数をむとに細分した14類型を示している。

（2）団地間の分担：複数団地から成る大学では、福利 厚生施設证中心団地（大学事務局庁舎が所在する団地） に重点的に設置さ㧈、他の団地は依存している可能性が ある。そこで、中心団地をメイン団地、他をサブ団地と して、単独団地加ら成る大学と区別した。

（3）団地の設置年度: 大学団地は、設置から時間が経 過するに従い、学生数の増加や組織の拡大により、大き く変容する。それに伴い、団地内で建詰まり現象を引き 起こし（丸茂、1989）、建設用地がなくなり、福利厚生 施設が整備されていない可能性がある。

（4）学生数: 学生数は福利厚生施設の規模を決定する 上で重要な変数である。

（5）校舎教地面積注3)：建物が建設される校舎敫地が 広ければ、将来の建設用地も広く、組織の拡大に伴い福 利厚生施設が不足した場合にす整備が容易である。

（6）学生一人当たり校舎敨地面積、及び校舎床面積注4) : 団地敫地の中で、校舎敫地及び校舎は実際に学生が頻 繁に利用するところである。そこで、学生一人当たり校 舎敷地面積及び校舎床面積と福利厚生施設との関連性を 探ることにした。

（7）建ぺい率及び校舎の容積率：容積率や建ぺい率は、 建設計画を立てる際に参照される。特に、課外活動施設 は通常の校舎から離れて建設されることも多い。そこで、 建ぺい率は団地の全敨地に対する校舎の建築面積の比率 とした。容積率は、全数地面積に対する校舎延面積の比 率が上記の建べい率と約0.90の相関を示すので、約0.70 である校舎政地に対する校舎延面積の比率を用いた。

（8）一棟当たり敷地面積: 福利厚生施設の中で、特に、 課外活動施設の建設用地は全散地が対象となる。団地内 

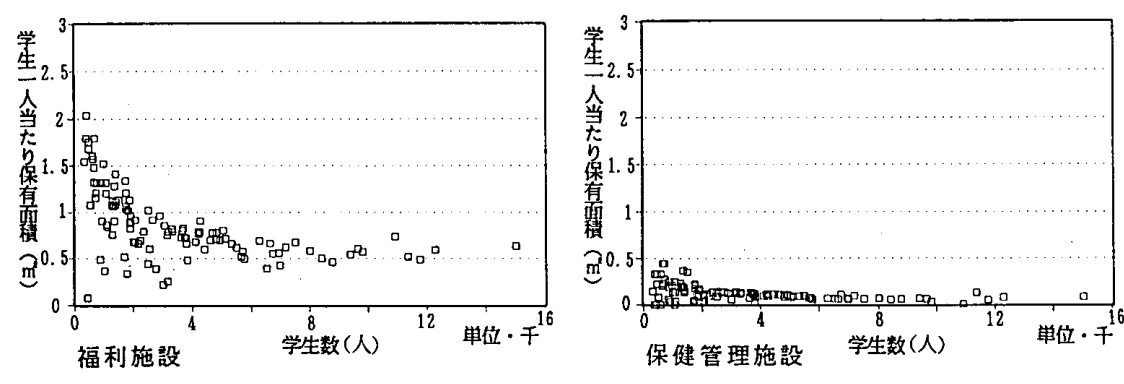

図 1 福利厚生施設の保有面積

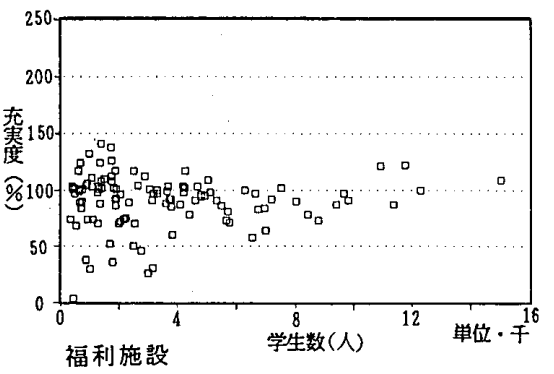

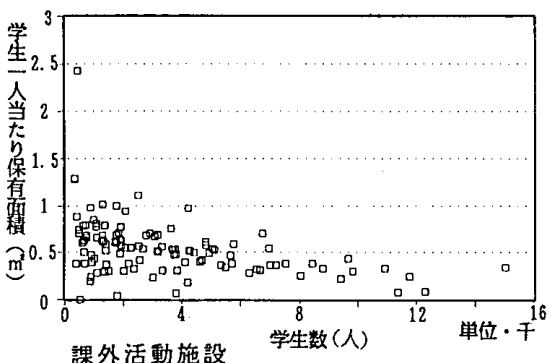

課外活動施設

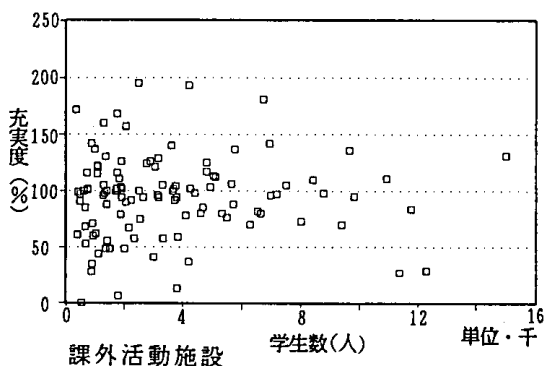

課外活動施設

図2 福利厚生施設の充害度

では小さな建物が多いほど建物棟数が多くなり、新たな 建設用地の確保が難しくなる。躈地面積と建物棟数は、 福利厚生施設の整備に個別に影響するというより、両者 の相対的な関係で影響を及ぼすと思われる。

\section{2 福利厚生施設の学生一人当たり整備状況}

福利厚生施設は全般的にみると、面積が最も大きいの が福利施設であり、次に課外活動施設、最む小さいのが 保健管理施設である。これは、施設を利用する学生数と 頻度を考慮して面積が決定されているためと考えられる。

まず、簡単に、各団地の学生一人当たりの面積と学生 数の関倸を調べるために、図 1 を作成した。学生一人当 たりの面積は、学生数が大きくなるほど減少する傾句を 示す。特に福利施設は、その傾向が強い。また、一人当 たり面積の差異は学生数が少ないほど大きい。

\section{3 福利厚生施設の充実度}

福利厚生施設の量的な整備状況を調べるのに、基準面 積に対する保有面積の比率を充実度の指標とした。福利 厚生施設の整備に関わると思われる団地特性と、充実度 との関係を検討した。団地特性を表す変数が連続量の場 合 2 変数プロット図、離散量である場合は箱ひげ図を用 いた。その結果の例として、図2、図3、図4を示した。 (1) 団地別に学生数と充実度の関係を調べたすのが図 2 である。充実度は全般的に団地間で差異がみられる。 特に、学生数が少ない団地でその傾向が強い。

課外活動施設は、他の福利厚生施設に比べて、充実度 が広く拡散し、整備差が大きい。また、保健管理施設は、 他の福利厚生施設に比べて充実度の低い団地が多い。保 健管理施設は、本来、学生や職員の健康管理を行うもの
であるが、日常的な使用頻度が低いので、たとえ充実度 が低くてす、大きな問題が生じないと考えられる。

以上より、福利厚生施設の整備は一般に遅れているが、 団地の実情に対応しながら整備されてきたと思われる。

（2）図 3、図4は、それぞれ学部構成による団地類型、 団地間の分担について箱ひげ図を作成したものである。 1）学部構成による団地類型: 団地の学部構成に上る類 型別に充実度の分布を調べた（図 3)。福利厚生施設を みると、総合型団地の分布は他の類型より狭く、工科系 型団地の分布は広いが、共に整備がわずかに遅れている。 また、農・水産系型団地む同様の傾向を示している。

類型別に詳細にみると、工科系型団地では保健管理施 設、課外活動施設の整備が遅れている。特に、保健管理 施設の分布が広く、団地間で整備の差が大きい。文科系 型団地は、課外活動施設でやや整備されているが、福利 施設、保健管理施設で整備が遅れている。

2) 団地間の分担: 図 4 より、福利厚生施設の中央値は 単独団地が最も高く、サブ団地は最も充実度が低く整備 が遅れている。単独団地の分布は狭いが、メイン団地と サブ団地の分布は広い。すなわち、複数の団地をるつ大 学では、平均的に整備する場合、あるいは、メイン団地 を主に整備しサブ団地をメイン団地に依存させる場合が 混在していると考えられる。特に、保健管理施設は、サ ブ団地で充実度が低く、メイン団地に依存している。こ れは、複数の団地が互に往来が容易な距離にあるならば、 職員や設備などの関係から、保健管理施設を分散するよ り集中する方が効率的であるためと思われる。 

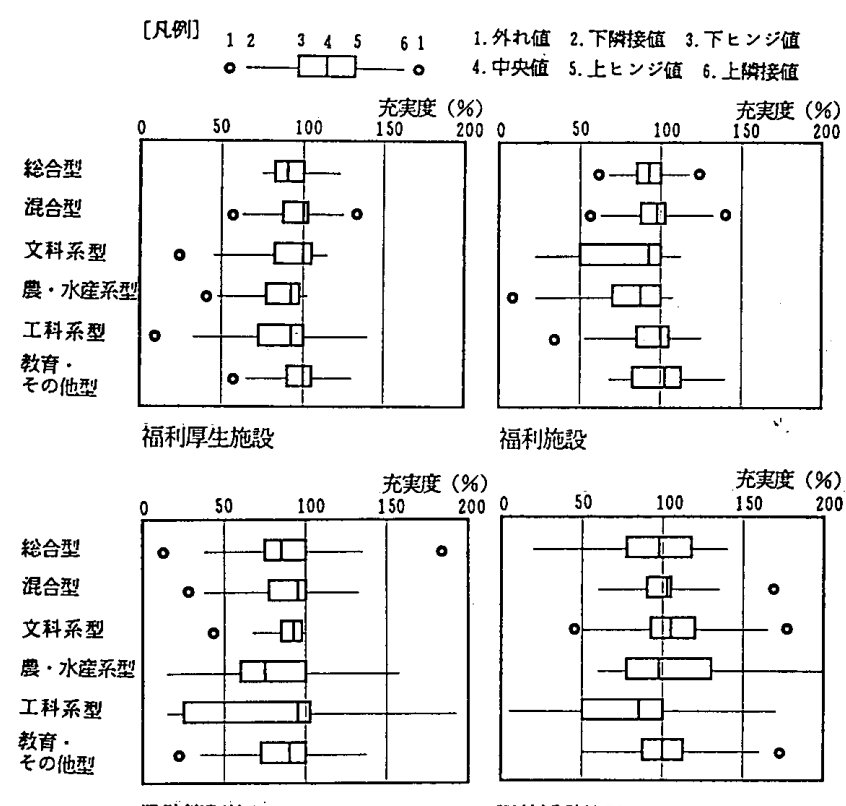

保健管理施設

致外活動施設

図3 団地類型による充実度の分布

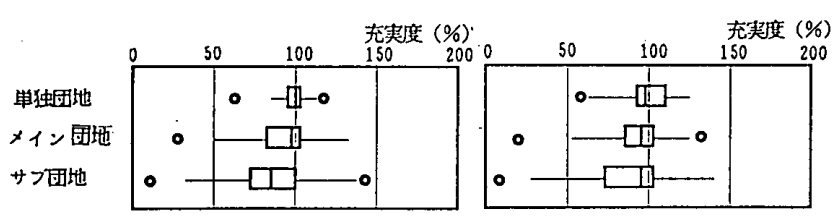

福利原生施啹 福利施設

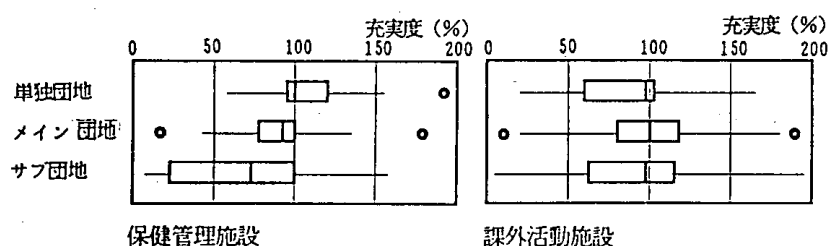

図4 団地間の分担による充実度の分布

\section{4. 福利厚生施設の複合状況}

平面図をみると、福利厚生施設は、校舎、管理施設な どの他の用途の施設と複合して建設される場合が多く、 複合状況の検討は必要である。

\section{1 建物別の複合状況の種類}

建物の平面図から、福利厚生施設の複合状況を次の 3 つに分ける方が、建物の用途が明確になると思われる。 すなわち、(1)福利施設、保健管理施設、課外活動施設別 にそれぞれ単独の建物をもつもの（以下、独立型と呼ぶ）、 (2)福利厚生施設間で複合しているむの（以下、同機能複 合型と呼ぶ）、(3)福利厚生施設と他の用途の施設が複合 しているあの（以下、他機能複合型と呼ぶ）である。

さらに、この複合状況の 3 分類を、福利施設、保健管 理施設、課外活動施設、他の用途の施設も含めた組み合 わせを考虑して14に細分類した。

\section{2 複合状況の分類別施設数}

表 3 は、複合状況別に施設数、棟数及び団地数を示し たものである。これより、次のことが考察できる。
表 3 福利厚生施設の複合状況

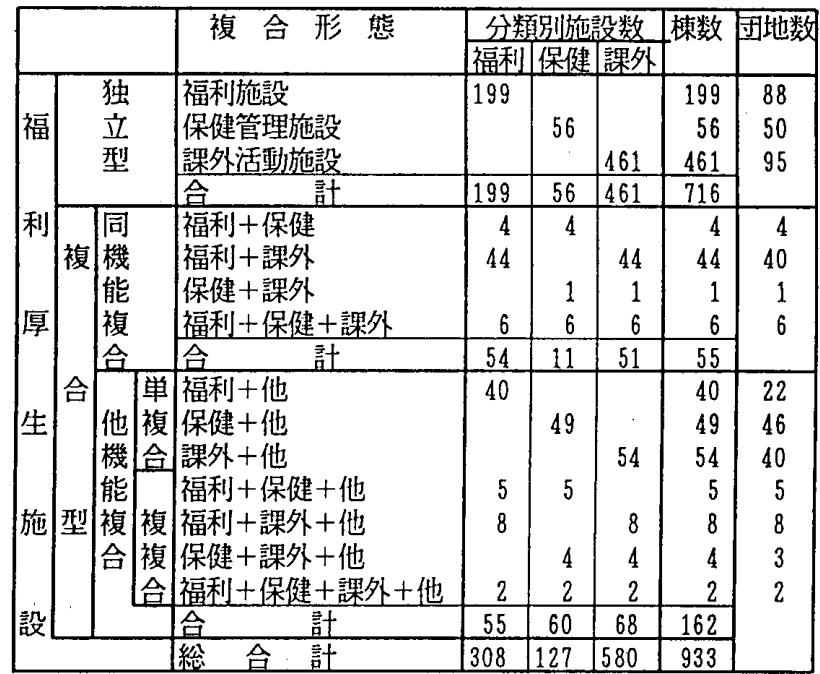

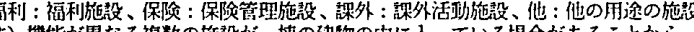

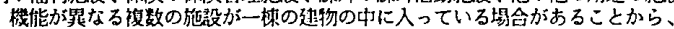
施設数と梀数を分けた

（1）福利施設は、88団地で独立型の建物をむち、複合 した建物よりも多い。ほとんどの団地では、少なくとも 1 つは大規模な食堂が計画され、これに購買や害籍など が含まれている。これは、食堂は機能的に広い空間が必 要であり、学生の出入りが頻繁で、サービス動線が必要 なことから、敷地に余裕があれば独立型の建物として計 画されることを示している。

（2）保健管理施設は他の福利厚生施設より多く複合し ている。保健管理施設は、管理施設を除き、他の用途の 建物と複合する機能的な必要性はないが、複合する割合 が高い。これには次の理由などが考えられる。

(1)保健管理施設の面積は団地の中では一般に小さく、小 さい建物の存在は将来の建詰まり現象を引き起こし、建 設用地不足につながる（山口、谷口、高野、1992年）。 (2)建設当時適当な建設用地がなかった。

（3）課外活動施設は、95団地で独立型の建物があり、 独立型の棟数は複合している建物よりあ圧倒的に多い。 課外活動施設は学生サークル部室が集合したすので、単 独の建物になる可能性が高い。その他、単独の建物にな りやすい理由として以下のことが考えられる。 (1)体育系の課外活動施設は、機能上、屋内運動場や運動 場などの施設の近くにあり、しかす、校舎数地の端部に ある場合が多い。したがって、建物の面積が小さくてる 将来の建設用地にあまり影響を及ぼさない。 (2)課外活動施設は、学生だけが利用し、管理上、特に他 の用途の施設との複合が難しい。

(3)課外活動施設の建設費が他の建物と比べて相対的に低 く、建設費の高い施設と複合化するのが困難である。 (4)課外活動施設は、計画的に建設するのが難しく、その 時の状況によって小規模です建設される。

一方、複合化の可能性は次のような例が考えられる。 
(1)食堂を含む大規模な大学会館などを建設する場合、文 化系の学生サークル部室などと複合化する。

(2)校舎内の都合できるスペースを課外活動用に転用する。

\section{3 建設年度別にみた福利厚生施設の複合状況}

近年、福利施設を整備する際には、大学会館として建 設されることが多い。しかす、大学会館は、福利施設だ けではなく、課外活動施設などと複合している場合が多 い。そこで、福利厚生施設の複合状況を、大学会館と大 学会館以外の施設に分けて検討することにした。

表 4 は、福利厚生施設の複合状況を建設年度別に大学 会館とそれ以外の施設に分けて棟数を示したものである。

大学会館は、昭和 30 年代、40年代には独立型と複合型 がほぼ同数であるが、昭和 50 年代には複合型の大学会館 の方が多く建設されている。

大学会館以外の複合型の福利厚生施設は、昭和 40 年代、 50 年代に多く現れている。これは昭和 40 年代半ばの学生 紛争で学生生活のための施設の要求が強まったこと、ま た、昭和51年の学生数は、昭和 34 年に比べると、2.68倍 に増加したことなどによるすのと思われる。

4.4 複合した福利厚生施設における機能間の関係

次に、福利厚生施設の機能的な複合状況をみるために、 福利施設、保健管理施設、課外活動施設及び他の9種類の 用途の施設との組み合わせを調べた。表 5 は大学会館、 表 6 は大学会館以外の建物について組み合わせである。

表 5 より、複合型である48棟の大学会館では、福利施 設と課外活動施設との複合が多い。特に文化系の学生サ ークル部室が食堂、売店などと複合化される場合が多い ものと思われる。これらは学生が利用する施設であり、 関連性が高いことを反映している。

表6より、大学会館を除く169棟の複合化された施設 の、機能上の組み合わせは次のとおりである。

福利施設、保健管理施設はそれぞれ学部校舎、管理施 設との複合が多い。これは、昭和40、50年代に福利厚生 施設の面積が不足したが、単独で建設するには面積が小 さかったので、学部校舎や管理施設の中に複合させなが ら整備したためと推測できる。保健管理施設と管理施設 は互いに管理上関係がある。また、福利施設は課外活動 施設との複合む多い。

課外活動施設は体育施設との複合が多い。これは、体 育系の課外活動施設が更衣室、シャワー室、運動器具倉 庫などを必要とするので、屋内運動場、屋外運動場附属 施設などと複合している場合が多いためと考えられる。 4.5 大学会館の存在と福利厚生施設の整備状況

大学会館の建設は福利厚生施設を整備する際の重要な 手段であり、建設直後は、福利厚生施設の面積が充足さ れる。一方、大学会館の建設後、時間が経過すると学生 数の增加などにより、福利厚生施設は再び面積が不足す る事態に陷る可能性があると考えられる。

\section{表4＼cjkstart複合状況の年代別变化}

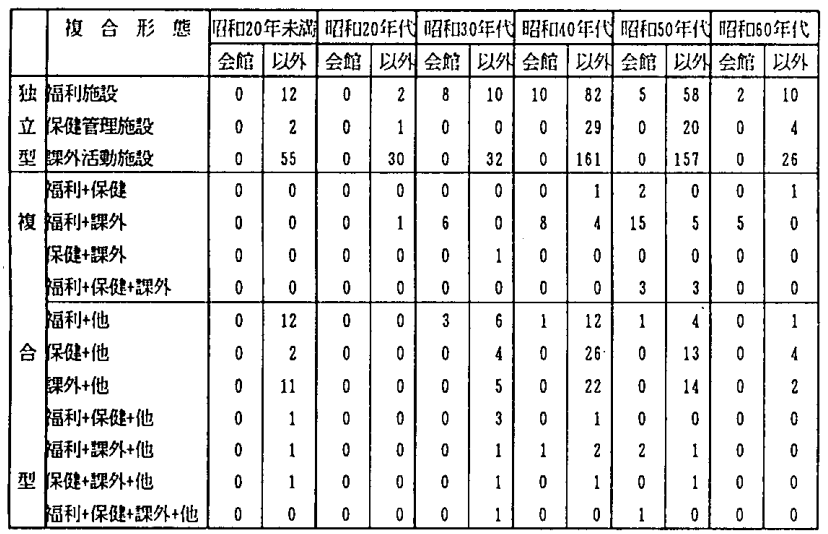

会馆 : 大学会馆、以外 : 大学会馆以外の施投

数値は梀数である 昭和60年代は炤和163年までである

\section{表 5 大学会館（48棟）の複合状況}

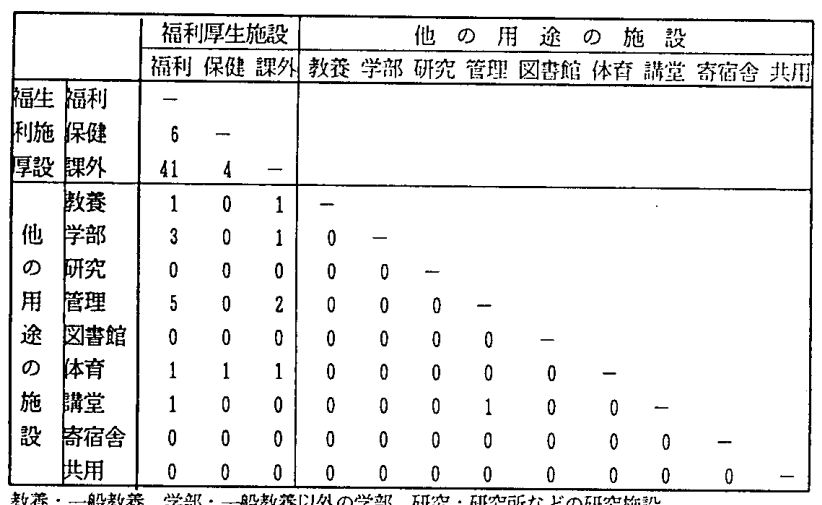

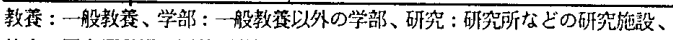

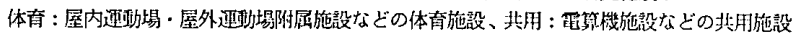

\section{表 6 大学会館以外の施設（169棟）の複合状況}

\begin{tabular}{|c|c|c|c|c|c|c|c|c|c|c|c|c|c|}
\hline & \multicolumn{3}{|c|}{ 福利厚生施設 } & \multicolumn{9}{|c|}{ 他の 用途の 施筂 } \\
\hline & & 福利 & 保健 & 課外 & 教籍 & 学部 & 砸勃 & 䈏跑 & 对菲合 & 体肖 & 唯党 & 突宔 & 基用 \\
\hline 融生 & 隔利 & - & & & & & & & & & & & \\
\hline 利施 & 保健 & $\Pi$ & - & & & & & & & & & & \\
\hline 厚設 & 锞外 & 19 & 9 & - & & & & & & & & & \\
\hline & 教差 & 11 & 8 & 5 & - & & & & & & & & \\
\hline 他 & 学部 & 22 & 27 & 22 & 5 & - & & & & & & & \\
\hline の & 研究 & 4 & 5 & 1 & 1 & 5 & - & & & & & & \\
\hline 用 & 管理 & 19 & 27 & 13 & 4 & 13 & 2 & - & & & & & \\
\hline 途。 & 図書館 & 9 & 11 & 2 & 4 & 12 & 3 & 3 & - & & & & \\
\hline の & 体青 & 4 & 2 & 32 & 0 & 1 & 1 & 3 & 1 & - & & & \\
\hline 施 & 講堂 & 2 & 2 & 2 & 0 & 3 & 0 & 1 & 2 & 0 & - & & \\
\hline 設 & 寄缩舎 & 0 & 1 & 0 & 0 & 0 & 0 & 1 & 0 & 0 & 0 & - & \\
\hline & 姑用 & 1 & 2 & 3 & 0 & 3 & 0 & 2 & 0 & 0 & 1 & 0 & - \\
\hline
\end{tabular}

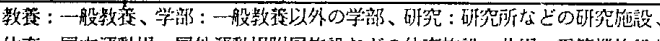

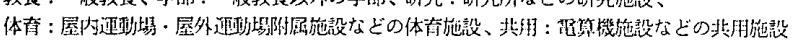

図 5 は、大学会館の設置年度別と大学会館のない場合 に分けて、充実度を示したものである。福利厚生施設全 体では、設置年度による差異は少ないが、大学会馆がな い団地では分布が広く、充実度も低い。特に、福利施設 は、大学会館建設により整備されるので、大学会館のあ る団地では分布が狭く、ない団地では分布が広い。また、 保健管理施設、課外活動施設の分布が福利施設より広い。 これは、大学会馆は、本来、福利施設を整備するもので あるが、場合に応じて保健管理施設や課外活動施設の整 
備にも用いられるという状況を反映している。

\section{6 福利厚生施設の複合率と整備状況}

(1) 施設の総延面積に対する複合型施設の延面積の割 合を複合率として、各団地別の分布を示した（表 7 ）。 (1)福利施設は複合率の分布が全体的に散らばっており、 各団地の事情により複合率の差異が大きい。 (2)保健管理施設は、面積が小さく、設備や職員などを考 えると、通常 1 つの団地で 2 つ以上設置する必要がない。 そのため、複合率が0\%と100\%の場合の両極に分かれる。 (3)課外活動施設は複合率の值が全般的に分布しているが、 低い值の方がやや多く、偏りがみられる。これは、全体 的にみると、例えば、体育系の学生サークル部室などの ように独立した建物が多いことを示している。

（2）福利厚生施設は、学生数が急增した昭和 40 年、 50 年代に施設を整備するために複合化が行われたと思われ る。施設の複合と整備の実態に関して論理的な関係は明 確ではないが、現象として、福利厚生施設の複合率が現 状の整備の充実と関わりをむつ可能性がある。福利厚生 施設の複合率と充実度の関係を示したものが図6である。 (1)福利施設では、複合率が高いほどやや分布が狭く、わ ずかに整備が進んでいる。これは、整備する福利施設の 面積が小さい場合は、福利施設と校舎、管理施設などと 複合する形で建物を建て、一方、整備する福利施設の面 積が大きい場合は、学生サークル部室など面積の小さい 施設を吸収する形で建物が建てられてきたことを示す。 いずれにせよ、面積のある程度大きい建物の方が、敷地 を細分化せず将来の建設用地を確保するため有効であり、 施設の管理む容易であることを裹付けている。

(2)保健管理施設は、各団地において保健管理センターあ るいは保健室として設置されている。充実度は、複合率 0\%の方が100\%のすのより相対的に值が高い。これは、保 健室の面積が小さく、通常、他の用途の建物の中に含ま れる形で複合されているためと思われる。

(3)課外活動施設では、複合率が低いほど充実度が高い。 これは、課外活動施設は、面積が小さくとす独立した建 物として整備されることが多いことを反映している。

\section{5.福利厚生施設の整備差に関する要因の分析}

学部構成による団地構成、団地の設置年度、校舎数地 面積などの団地特性、及び、複合状況、大学会館の有無 と設置年度が相互にどのように関連し、これらの特性が 大学団地における福利厚生施設の整備とどのような関わ りをむってきたかを検討するために、福利厚生施設の充 実度を外的基準として数量化 I 類注5）を行った（表 8）。

（1）福利厚生施設をみると、学生数、団地の設置年度、 団地間の分担のレンジ幅が広く、これらの特性が整備と 何らかの関係があったことを示している。
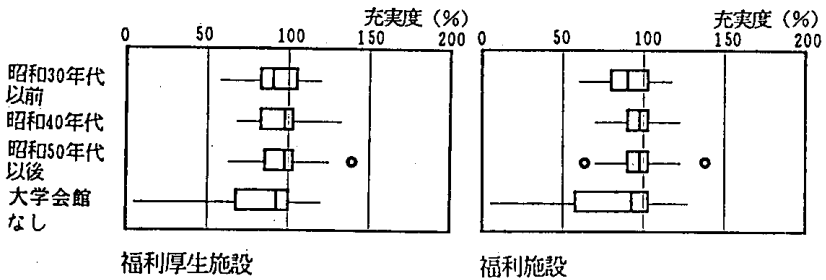

福利施設

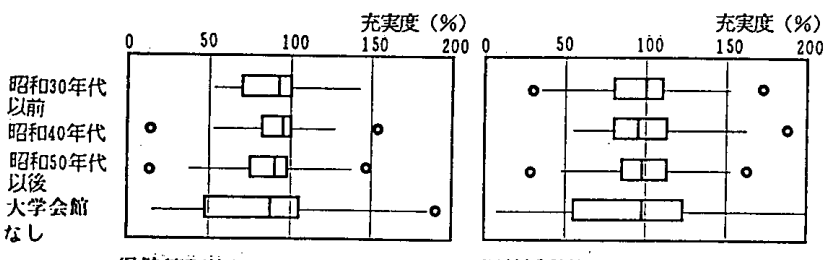

保健管理施設

課外活動施犋

図 5 大学会館による充実度の分布

表 7 複合率の分布

\begin{tabular}{|c|c|c|c|c|c|c|c|c|c|c|c|}
\hline & $1 \%$ & $10 \%$ & $20 \%$ & $30 \%$ & $40 \%$ & $50 \%$ & $60 \%$ & $70 \%$ & $80 \%$ & $90 \%$ & \\
\hline & 1 & | & 1 & | & | & 1 & 1 & 1 & | & 1 & \\
\hline$p \%$ & $9 \%$ & $19 \%$ & $29 \%$ & $39 \%$ & $49 \%$ & $59 \%$ & $69 \%$ & $79 \%$ & $89 \%$ & $99 \%$ & $100 \%$ \\
\hline 福利厚生 11 & 19 & 11 & 9 & 12 & 10 & 10 & 12 & 5 & 4 & 1 & 8 \\
\hline 福 利 10 & 4 & 6 & 5 & 6 & 3 & 8 & 7 & 5 & 2 & 2 & 24 \\
\hline 保健管理 19 & 0 & 0 & 0 & 0 & 0 & 0 & 0 & 0 & 0 & 0 & 59 \\
\hline 課外活動 31 & 13 & 9 & 11 & 12 & 4 & 6 & 6 & 2 & 1 & 0 & 16 \\
\hline
\end{tabular}

数値付四地数てある

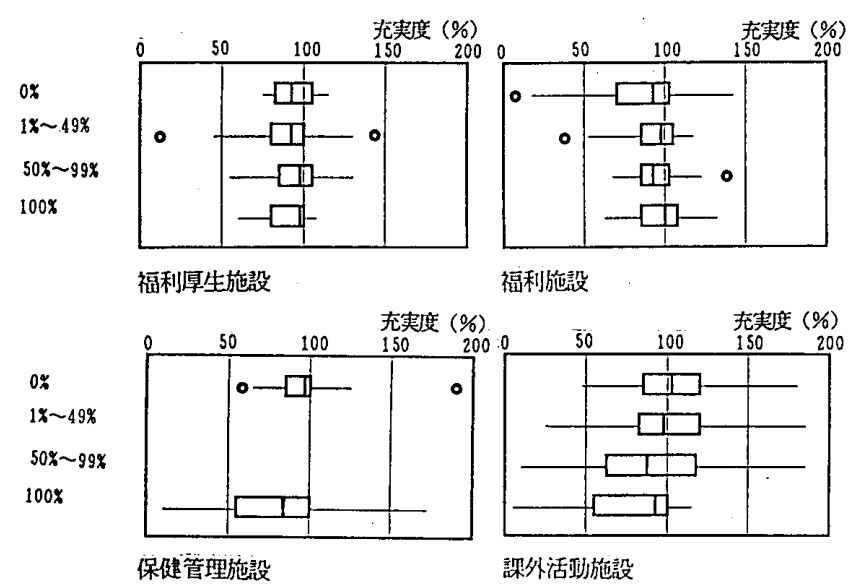

図6 複合率による充害度の分布

カテゴリ一別にみると次のとおりである。1)福利厚生 施設が相対的に充実している団地は、単独団地、昭和以 前に設置された団地、学生数 2000 人未満である。2)整備 が相対的に遅れている団地は、昭和 40 年代に設置された 団地、学生一人当たり校舎敷地面積が $100 \mathrm{~m}^{2}$ 以上で、学生 数が 3000 人以上 4000 人未満の団地である。

(1)福利施設では、学生一人当たり校舎敷地面積、学部構 成による団地類型、学生一人当たり校舎床面積のレンジ 幅が広い。カテゴリースコアをみると、1)学生一人当り 校舎床面積 $30 \mathrm{~m}^{2}$ 以上、学生数 2000 人未満、教育. その他 型の団地が高い值を示し、2)学生一人当り校舎敷地面積 $100 \mathrm{~m}^{2}$ 以上、農 ·水産系型団地、学生一人当たり校舎床面 積 $20 \mathrm{~m}^{2}$ 未満、学生数 5000 人未満、大学会館がない団地な 
表 8 数量化 I 類電算処理結果

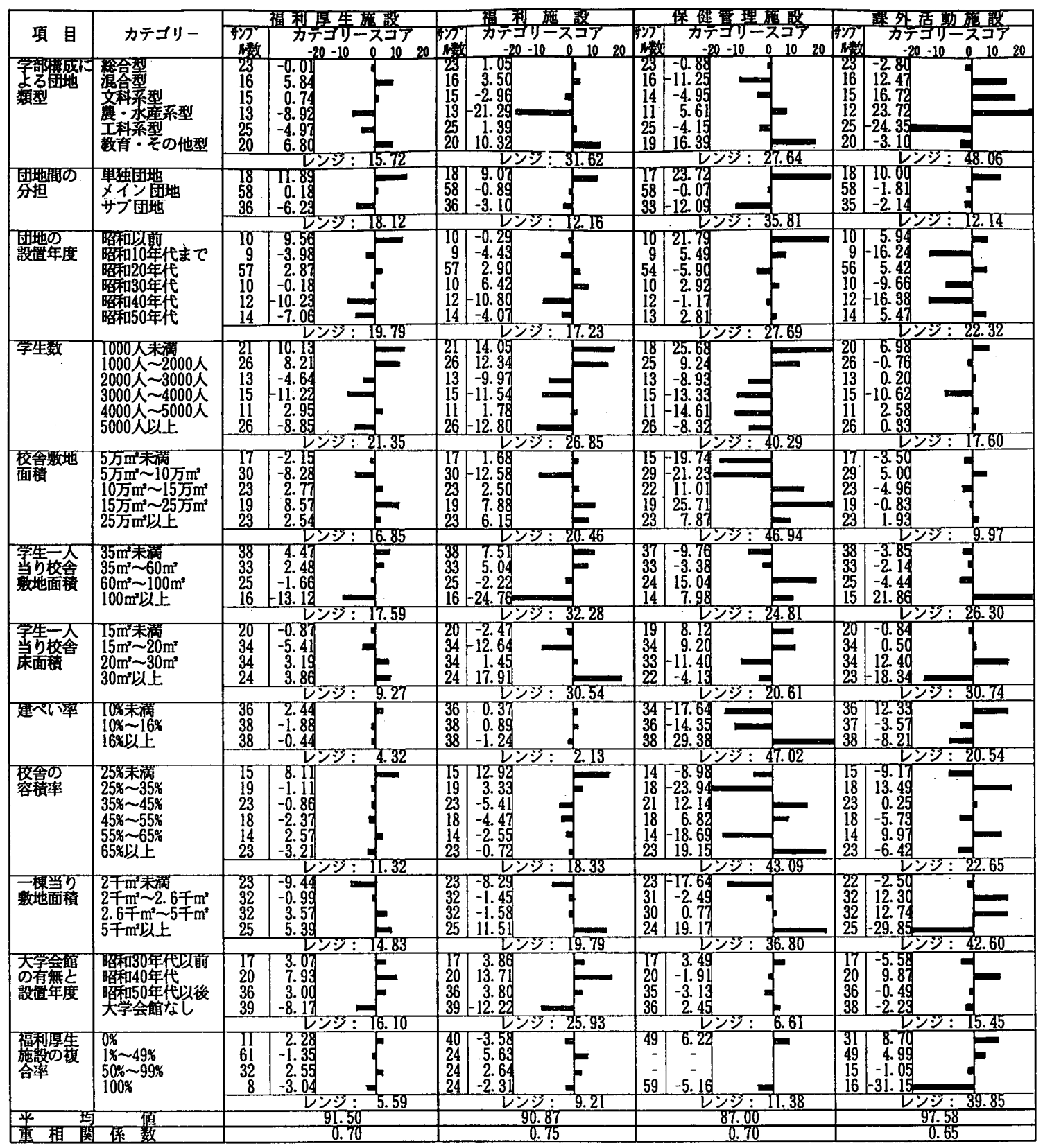

どが低い值を示している。

(2)保健管理施設では、建ぺい率、校舎敨地面積、校舎の 容積率のレンジ幅が広い。カテゴリースコアをみると、 1) 建ぺい率が $16 \%$ 以上、校舎敷地面積が 10 万 $\mathrm{m}^{2}$ 末満が高い 值を示し、2)建ぺい率が $16 \%$ 末満と校舎数地面積が 10 万 $\mathrm{m}^{2}$ 未満が低い值を示している。

(3)課外活動施設では、学部構成による団地類型、一棟当 たり敷地面積、福利厚生施設の複合率のレンジ幅が広い。 カテゴリースコアをみると、1)文科系・農・水産系型団 地、一棟当たり敨地面積が 2 千 $\mathrm{m}^{2}$ 以上 5 千 $\mathrm{m}^{2}$ 末満、複合率 が50以下が値が高く、2)工科系型団地、一棟当たり教地 面積が 5 千 $\mathrm{m}^{2}$ 以上、複合率が $100 \%$ が低い值を示している。 （2）団地特性と福利厚生施設整備の充実度の関係につ いて、福利厚生施設の整備で重要と思われる複合率、大
学会館の有無と設置年度、団地間の分担関係をみると、 既に得られたことが再確認できる。例えば、複合率の力 テゴリースコアより、福利施設は独立型、完全に複合型 がマイナス要因になり、何らかの形で複合化されながら 整備されてきたことを襄付けている。一方、保健管理施 設、課外活動施設は複合率が低いほどプラス要因になり、 独立型の建物として整備されてきた経緯を示す。

\section{6.まとめ}

（1）福利厚生施設は全般的に整備がやや遅れており、 団地間の差異むみられる。施設種類別にみると、保健管 理施設、課外活動施設のばらつきが福利施設より大きい。 一般に、福利厚生施設の整備は、校舎の量的整備を優先 
する中で遅れる傾向にあったが、各団地の実態に即して 一律ではなく、緊急性を考慮しながら整備を行うことで 対処してきたように思われる。この結果、福利厚生施設 の整備は、次のように学部構成別あるいはメイン団地か サブ団地などにより差異がみられる。

(1)学部構成による団地類型別にみると、福利厚生施設全 体では、工科系型、農・水産系型でやや整備が遅れてい る。福利施設は農・水産系型と文科系型が、保健管理施 設では混合型と工科系型が、課外活動施設では工科系型 が整備がやや遅れている。

(2)大学における団地間の分担関係から整備状況をみると、 サブ団地は整備が遅れているが、メイン団地の施設に依 存していると考えられる。これは、保健管理施設につい て職員や設備などの関係加分散するよりは集中する方 が効率的であるためと思われる。

（2）福利厚生施設を整備するために、独立した建物を 建てる以外に、大学会館と複数施設の複合化による建物 の建設という方法が併用されている。大学会館も当初か ら複合化されたものが約半数を占め、一方、大学会館以 外の福利厚生施設を含む複合型の建物は、昭和 40 年代、 50 年代に多く建設された。後者の複合化された建物は、 この時期における学生の急増に関わりがあると思われる。 福利厚生施設が不足した場合、小さな独立した建物を 建てて整備したケースもあったと思われる。その場合、 小さい建物の存在は将来の建詰まり現象を引き起こし、 建設用地不足につながる可能性が大きい。福利厚生施設 を含む複数の施設をまとめて、ある程度大きな建物を建 てたことは、用途の混在を招いたが、将来の建設用地を 確保するために有効であったと思われる。

（3）福利厚生施設の機能からみた 3 つの分類別に得ら れた本編での結果を整理すると次のとおりである。

(1)福利施設住、食堂が広い空間を必要とし、学生の出入 りが多いため本来は独立型の建物として計画されると考 えられる。しかし、近年では、福利施設は、整備の際、 他の機能の施設と複合化する例が多くみられ、複合率が 高い団地ほどわずかに整備が進んでいる。恐らく、整備 する面積が小さい場合、学部校舎、管理施設などと複合 する形で建物を建て、一方、整備する面積が大きい場合、 大学会館として学生サークル部室など面積の小さい施設 を吸収する形で建物が建てられできたためと思われる。 (2)保健管理施設は、各団地で保健管理センターあるいは
保健室が設置される。この施設は面積が小さく、学部校 舎、管理施設などと複合して建てられる事例が多い。 (3)課外活動施設は、学生サークル部室が集合したもので、 独立型の建物が圧倒的に多い。複合する場合、屋内運動 場、屋外運動場附属施設などとの事例が多く、大学会館 と複合する事例もみられる。床面積からみると、複合率 （複合している比率）が低い団地ほど整備されており、 通常、面積が小さくとも独立の建物として建てられる。

注

1)文部省では、大学キャンバスのことを大学団纨と称し、「国立大学の施侮 か存在するか、または施設を整備しょうとしている一団地の土地。また、 一団地とは、用途上不可分の関係にあり、まとまった一区画の土地之社会 通念上認的られる土地をいう。」と定義している。

2)福利厚生施設の基準面積は、学生数を变数とする式で計算されるが、おそ らく行政上の判断や財政事情なども考虑して定められたものであり、面積 に十分であることを保証するすのではない。

3)団地の敖地の中で屋外運動場敖地、附属研究所数地、実験実習地、寄宿舎 地を除いた学部校舎施設、福利厚生施設、屋内運動場、講堂、管理施設、 図害館などの建策散地及びその周艿の敷地の面皘を校舎敨地面積とする。 4)ここでの校舎床面皘は、学部校舎施殿、福利厚生施钤、屋内運動場、講堂、 管理施設、図書館の延床面積とする。

5)多重共線性の問題を避けるために、12項目間の相関係数が0.80末満である こと、さらに、12項目の55カテゴリー（保険管理施設の場合は53カテゴリ 一) 間の相関係数が0.80以下であることを確認した。また、一般に、心理 的に評定された間隔尺度を目的变数として数墨化 I 類で分析する場合、比 較的容易に高い重相関係数が得られるようである。しかし、本研究のよう に物理的指標を目的变数にした場合、既往研究をみる限り、重相関保数は 相対的にやや低い。

\section{参考文献}

1)小林秀彌 : 大学とその付属施設の建筑、日本学術振興会刊、1965年

2)小林秀彌 : 大学キャンパス計画、彰国社、1978年

3) 日本建筑学会編：建筑学便覧 I 計画、丸善株式会社、PP. 397-438、1980年 4) 田中豊、脇本和昌 : 多変量統計解析法、現代数学社、PP. 138-151、1992年 5)岩坪秀一：数量化法の基礎、朝倉贵店、PP. 1-66、1991年

6)渡刀洋、鈴木則夫、山田文康、大塚雄作：探索的デー夕解析入阴、朝倉書 店、PP. 5-48、1985年

7)柳井晴夫、高木廣文 訳 : 探索的デー夕解析の方法、朝倉害店、PP. 1-29、 1981年

8)竹内啓、市川伸一、大橋靖雄 : S A S によるデー夕解析入門、東京大学出 版会、PP. 125-134、1990年

9)竹内敬、高橋行雄、大橋立教、劳賀敏郎：S A S による实験デー夕の解析、 東京大学出版会、PP. 203-224、1989年

10) 日本建筑学会 編 : 建築・都市計画のための調査・分析方法、井上書院、 PP. 123-128、1988年

11)山口勝巳、谷口汎邦、高野文雄 : ”国立大学におけるキャンパス計画なら びに施設・摆境に関する問題の構造化”、日本建築学会計画系覦文報告集、 第439号、PP. 45-53、1992年

12）丸茂弘幸: 国立大学キャンバスにおける土地利用の低効率化要因に関する 研究、日本都市計画学術研究論文集、24号、PP181-186、1989年

13) 谷口汎邦、高野文雄、宮本文人、山口勝已、森本修弥: ” 国立大学扵地の 郑型化と施設等の特徽についてー大学のキャンパス計画に関する研究その 1-"、日本建築学会大会学術謴演梗摡集、PP. 1613-1614、1984年

14) 高野文雄、谷口沉邦、長坂潤一、佐藤英幸 : " 国立大学学部組織瓶成姴素 の実態とその特性一国立大学学部校舎の建築計画に関する基礎的研究その 1 -" 、日本建築学会大会学術講演梗概集、PP. 667-668、1985年

(1993 年 7 月 9 日原稿受理, 1994 年 2 月 3 日採用決定) 